\title{
A Review on Therapeutic Benefits of Active Chemical Moieties Present in Polyalthia longifolia
}

\begin{abstract}
THONANGI CHANDI VISHALA, HO VIET HIEU ${ }^{1}$, K. N. KILLARI*, S. K. RANAJIT ${ }^{2}$, S. SAMANTH, HARITHA POLIMATI, ALEKHYAKETHA, SATYA SOWBHAGYA PRIYAANNAM, SRILAKSHMI NALLAPATY ${ }^{3}$, SREE TEJAKONERU ${ }^{3}$ AND ANNAPURNA AKULA

Department of Pharmacology, AU College of Pharmaceutical Sciences, Andhra University, Visakhapatnam 530003, India, ${ }^{1}$ Department of Medical Microbiology and Parasitology, Faculty of Medicine, Duy Tan University, Da Nang 550000, Vietnam, ${ }^{2}$ School of Pharmacy, Centurion University of Technology and Management, Odisha 767001, ${ }^{3}$ Department of Pharmaceutical Sciences, K. L. College of Pharmacy, Koneru Lakshmaiah Education Foundation, Green Fields, Vaddeswaram, Guntur, Andhra Pradesh 522502, India
\end{abstract}

Vishala et al: Chemistry and Pharmacology of Polyalthia longifolia

\begin{abstract}
Polyalthia longifolia (Annonaceae family) is native to the drier areas of India and is locally called "Ashoka." It is also cultivated in Southeast Asia, Africa, Australia and New Zealand. Polyalthia longifolia is also known as Buddha tree, mast tree, cemetery tree, false Ashoka or green Champa. Generally, Polyalthia longifolia is viewed as a street tree because of its effectiveness in combating noise pollution. Macroscopically, the versatile Polyalthia longifolia can reach over $15.0 \mathrm{~m}$ high with symmetrical pyramidal growth and weeping pendulous branches. The term Polyalthia is derived from Greek roots, with "poly" meaning many and "althia" meaning cure, indicating that this plant has been used to treat various diseases/disorders. In traditional and indigenous systems of medicine, Polyalthia longifolia has been commonly used in the treatment of fever, helminthiasis, diabetes and various cardiac problems. Pharmacological investigations have shown that Polyalthia longifolia possesses significant biological and pharmacological activity, which may include antibacterial, antifungal, antitumor, anti-ulcer, antidiabetic and antioxidant properties. To date, more than 30 studies have analyzed extracts from bark, leaves, roots, seeds, etc. of the plant and reported a total of approximately 100 compounds, including steroids, flavonoids, clerodane diterpenes, cleroda-oic acids and alkaloids. In context of the broad medicinal potential of Polyalthia longifolia, this review compiles a detailed exploration of currently available knowledge of the phytochemical and their pharmacological properties of Polyalthia longifolia. Its potential applications in the treatment of various conditions are also discussed.
\end{abstract}

Key words: Polyalthia longifolia, pharmacological applications, therapeutic applications, phytochemicals

The Polyalthia genus belongs to Annonaceae family, which consists of approximately 350 species distributed mostly in the regions of Southeast Asia, Africa, Australia and New Zealand ${ }^{[1]}$. Polyalthia longifolia (P. longifolia) is also known as Buddha tree, mast tree, cemetery tree, false Ashoka or green Champa. Generally, P. longifolia is viewed as a street tree because of its effectiveness in combating noise pollution ${ }^{[2]}$. Macroscopically, the versatile $P$. longifolia can reach over $15.0 \mathrm{~m}$ high with symmetrical pyramidal growth and weeping pendulous branches. There are two varieties of P. longifolia, namely "var. pendula" which has a straight slim trunk and short branches and "var. angustifolia" which has wide spreading branches forming a pyramidal crown with grey and smooth bark ${ }^{[1]}$.

*Address for correspondence E-mail: kishorenaidu.killari@gmail.com
The term Polyalthia is derived from Greek roots, with "poly" meaning many and "althia" meaning cure, indicating that this plant has been used to treat various diseases/disorders. In Ayurveda, herbal preparations of $P$. longifolia have been mainly used to treat duodenal ulcers while decoctions of the plant have been used in the treatment of fever, diabetes and skin diseases in various traditional medicine systems ${ }^{[1,3,4]}$. Furthermore, the bark and leaves of $P$. longifolia have been used to

\footnotetext{
This is an open access article distributed under the terms of the Creative Commons Attribution-NonCommercial-ShareAlike 3.0 License, which allows others to remix, tweak, and build upon the work non-commercially, as long as the author is credited and the new creations are licensed under the identical terms
}

Accepted 01 July 2021 Revised 08 March 2021 Received 03 June 2020 Indian J Pharm Sci 2021;83(4):634-647 
treat microbial infection, inflammation, diabetes and multiple diseases of the digestive system ${ }^{[1,3]}$.

Earlier reviews on the genus Polyalthia ${ }^{[3,4]}$ and plant P. longifolia ${ }^{[1]}$ summary the general phytochemistry and pharmacological activities of Polyalthia extracts. To our knowledge, there is no review on the therapeutic applications of chemical constituents of $P$. longifolia, till date. Therefore, in the current study, we aim to provide an overview of the phytochemistry and their pharmacological investigations to describe the many uses of this medicinal plant.

\section{PHYTOCHEMISTRY}

P. longifolia extract consists mostly of steroids, flavonoids, clerodane diterpenes, cleroda-oic acids

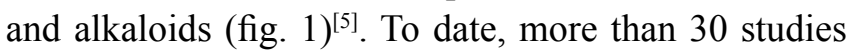
have analyzed extracts from bark, leaves, roots, seeds, etc., of the plant and reported a total of approximately 100 compounds (Table 1). The main compounds of the plant that have been identified and reported in multiple studies are beta $(\beta)$-sitosterol (1A), leucocyanidin (2A), proanthocyanidin (2B), 16 Alpha $(\alpha)$-hydroxycleroda-3,13(14)Z-dien-15,16-olide (3A), $(4 \rightarrow 2)$-abeo-16(R and S)-2,13Z-kolava-dien-15,16olide-3-al (3K), 16-oxo-cleroda-3,13(14) E-dien-15oic acid (4A), cleroda-3,13E-dien-15-oic acid (4B), liriodenine $(5 \mathrm{~F})$, solidagonal acid $(4 \mathrm{~N})$ and labd-13Een-8-ol-15-oic acid (4J) (Table 1).

Seven steroids have been isolated from this plant (fig. 2). 1A was one of the earliest steroids to be identified from the ethanolic extract of stem bark ${ }^{[6]}$. Afterward, several other groups analyzed extracts from leaves ${ }^{[7,8]}$, stems ${ }^{[9,10]}$, roots ${ }^{[11]}$ and bark $^{[12]}$ and identified six others, namely stigmasterol (1C), stigmasterol3- $\beta$-D-glucoside (1D), stigmasterol-3,5-diene (1G), stigmast-5-en-3-O- $\beta$-D-glucoside tetraacetate $(1 \mathrm{~J})$, $\beta$-sitosterol-D-glucoside (1O) and longitriol (1T). None of these compounds have been reported for their bioactivities.

In addition, 9 flavonoids have been isolated and reported from $P$. longifolia (fig. 3). Of these, 2A and $2 \mathrm{~B}$ were among the earliest flavonoids identified from the stem bark extract of this plant ${ }^{[6]}$. Later, chemical examination of butanol fraction of leaf extract yielded 5 known compounds (2C, 2D, 2E, 2 F and $2 \mathrm{G}$ ) with good scavenging of free radicals ${ }^{[13]}$. The other study on the ethanolic extract of $P$. longifolia leaves, using thin-layer chromatography (TLC) and reverse phase high-performance liquid chromatography (RP-HPLC), identified 3 more flavonoids (2G,2H and 2I), which showed antimicrobial, antioxidant and anti-cancer potential ${ }^{[14]}$. 27 clerodane diterpenes have also been isolated from P. longifolia (fig. 4). Two major compounds that have been repeatedly identified in the extract of leaves, stem bark, root bark and berries of this plant were $3 \mathrm{~A}$ and $3 \mathrm{~K}$ (Table 1 ). The remaining compounds were reported by several other studies ${ }^{[7,8,12,15-23]}$.

Moreover, 22 cleroda-oic acids with diverse bioactivities have also been identified (fig. 5), of which $4 \mathrm{~A}, 4 \mathrm{~B}, 4 \mathrm{~N}$ and $4 \mathrm{~J}$ have been repeatedly reported

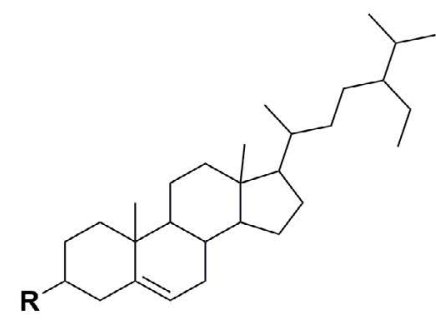

Steroids

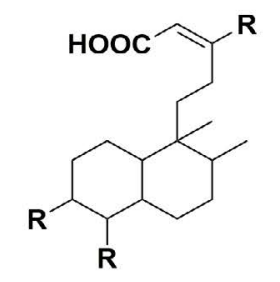

Cleroda-oic acids<smiles>[R]c1cc(C2Oc3cc(O)c([R])c([R])c3C(=O)C2[R])cc([R])c1[R]</smiles>

Flavonoids

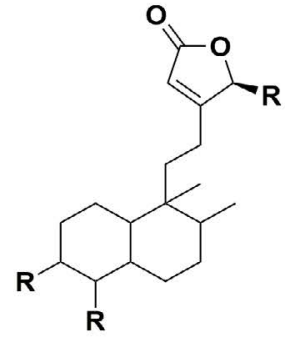

Clerodane diterpenes

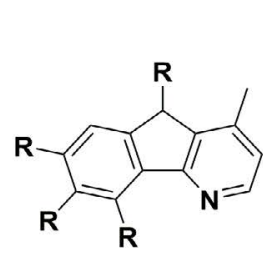

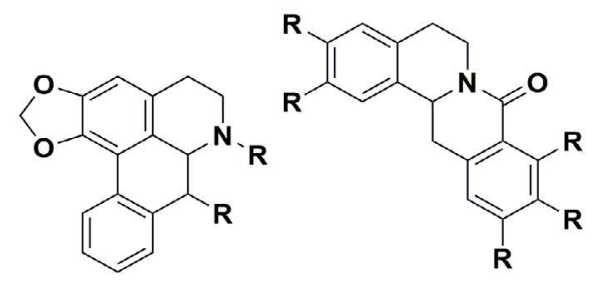

Alkaloids

Fig. 1: Core chemical structures of secondary metabolites reported from $P$. longifolia including steroids, flavonoids, clerodane diterpenes, cleroda-oic acids and alkaloids 
TABLE 1: SECONDARY METABOLITES ISOLATED AND REPORTED FROM DIFFERENT PARTS OF $P$. longifolia AND THEIR BIOLOGICAL IMPORTANCE

\begin{tabular}{|c|c|c|c|c|}
\hline Part used & Solvent Used & Isolated compound(s) & Biological activity & Reference \\
\hline \multirow{3}{*}{ Bark } & Petroleum ether & $3 \mathrm{~B}$ & - & [15] \\
\hline & \multirow[t]{2}{*}{ Methanol } & $\begin{array}{c}1 \mathrm{~A}: 1 \mathrm{C}(3: 1), 1 \mathrm{D}: 10(1: 4), \\
1 \mathrm{H}-\mathrm{N} / \mathrm{N}^{\prime}, 3 \mathrm{~A}, 3 \mathrm{C}, 3 \mathrm{~K}, 3 \mathrm{~N}- \\
0,4 \mathrm{~J}, 4 \mathrm{~L}-\mathrm{N}, 5 \mathrm{~A}, 5 \mathrm{~F}, 5 \mathrm{~J}, 5 \mathrm{R} \\
5 \mathrm{Y}, 5 \mathrm{Z}, 5 \mathrm{AA}\end{array}$ & $\begin{array}{c}3 \mathrm{~A}, 3 \mathrm{C} \text { and } 30 \text { showed significant cytotoxicity } \\
\text { activity and } 4 \mathrm{~L} \text { showed better anti-inflammatory } \\
\text { activity, compared to other compounds. }\end{array}$ & [12] \\
\hline & & $3 S$ & - & [23] \\
\hline \multirow[t]{7}{*}{ Berries } & Methanol & $1 \mathrm{E}$ & - & [19] \\
\hline & Acetone & $3 \mathrm{~A}, 4 \mathrm{~A}$ & Both exhibited significant antifeedant activity & [24] \\
\hline & Butanol fraction & $2 C-G, I E$ & $\begin{array}{l}\text { Only } 2 \mathrm{C}, 2 \mathrm{D} \text {, and } 2 \mathrm{G} \text { showed significant } \\
\text { antioxidant activity compared to ascorbic acid. }\end{array}$ & [13] \\
\hline & & $\begin{array}{l}\text { 1S, 3A, 3K, 3P, 4A, 4I-J, 4S, } \\
5 F-G, 5 T, 5 A I\end{array}$ & $\begin{array}{l}\text { Among all, } 3 \mathrm{~A} \text { was found to be most potent agent } \\
(\mathrm{MIC}=6.25 \mu \mathrm{g} / \mathrm{ml} \text { against } \mathrm{S} \text {. aureus and Sporothrix } \\
\text { schenckii). }\end{array}$ & [20] \\
\hline & & $3 \mathrm{~A}$ & $\begin{array}{l}\text { 3A was found to be a potential antileishmanial } \\
\text { activity. }\end{array}$ & [30] \\
\hline & Ethanol & $1 \mathrm{~T}, 3 \mathrm{~L}, 3 \mathrm{R}$ & $\begin{array}{l}1 \mathrm{~T} \text { and } 3 \mathrm{R} \text { were active against C33A cell lines. } \\
\text { Only } 2 \mathrm{G} \text { showed significant antibacterial, }\end{array}$ & [8] \\
\hline & & $2 \mathrm{G}-\mathrm{I}$ & $\begin{array}{l}\text { antiradical, and cytotoxicity activity compared } \\
\text { to the standards. }\end{array}$ & [14] \\
\hline \multirow[t]{8}{*}{ Leaves } & & $3 \mathrm{~A}, 3 \mathrm{P}, 3 \mathrm{~W}, 4 \mathrm{~A}$ & $\begin{array}{l}\text { Only 3A showed pronounced lipid lowering } \\
\text { activity. }\end{array}$ & [31] \\
\hline & Ethyl Acetate & $3 A, 4 A-B$ & $\begin{array}{l}\text { 4A and } 4 \mathrm{~B} \text { had better apoptotic potentiality } \\
\text { against } \mathrm{HL}-60 \text { cells than } 3 \mathrm{~A} \text {. }\end{array}$ & [32] \\
\hline & Hexane fraction & $3 \mathrm{~A}, 3 \mathrm{P}-\mathrm{Q}, 4 \mathrm{~A}$ & All are effective cytotoxic agents. & [21] \\
\hline & & $5 \mathrm{~A}-\mathrm{H}$ & - & [28] \\
\hline & \multirow{4}{*}{ Methanol } & $\begin{array}{c}1 \mathrm{~A}-\mathrm{C}, 3 \mathrm{~A}, 3 \mathrm{~J}-\mathrm{K}, 4 \mathrm{~B}, 4 \mathrm{H}-\mathrm{J} \\
5 \mathrm{~F}-\mathrm{G}, 5 \mathrm{M}-\mathrm{U} / \mathrm{U}\end{array}$ & $\begin{array}{l}\text { Only } 3 \mathrm{~A}, 5 \mathrm{Q} \text {, and } 5 \mathrm{G} \text { were tested for cytotoxicity } \\
\text { and found to be active against HA59T cells. } \\
4 \mathrm{H} \text { significantly inhibited the release of elastase }\end{array}$ & [7] \\
\hline & & $4 \mathrm{H}$ & $\begin{array}{l}\text { in FMLP/CB-activated human neutrophils } \\
\text { (IC50 }=3.30 \pm 0.48 \mu \mathrm{m})\end{array}$ & [25] \\
\hline & & $3 \mathrm{~A}$ & $\begin{array}{l}\text { 3A exhibited significant anti-MRSA activity } \\
\text { compared to a B-lactam antibiotic. }\end{array}$ & [33] \\
\hline & & $4 \mathrm{~V}$ & $\begin{array}{l}\text { 4V did not exhibit significant inhibitory effect } \\
\text { against HL-60 cells. }\end{array}$ & [34] \\
\hline $\begin{array}{l}\text { Leaves and } \\
\text { berries }\end{array}$ & Methanol & $3 \mathrm{~A}, 3 \mathrm{~K}, 30-\mathrm{P}, 4 \mathrm{~A}, 4 \mathrm{~L}, 40$ & $\begin{array}{c}\text { Except } 4 \mathrm{~L} \text { and } 40 \text {, all are active antimicrobial } \\
\text { agents with MIC values ranging between 7.8-500 } \\
\qquad \mu \mathrm{g} / \mathrm{ml} \text {. }\end{array}$ & [19] \\
\hline Root & Methanol & $1 \mathrm{D}-\mathrm{E}, 4 \mathrm{~B}, 5 \mathrm{Q}, 5 \mathrm{~V}-\mathrm{X}$ & $\begin{array}{l}\text { Only } 5 \mathrm{~V} \text { and } 5 \mathrm{~W} \text { showed good antimicrobial } \\
\text { activity with MIC values of } 0.02-20 \mu \mathrm{g} / \mathrm{ml} \text {. }\end{array}$ & [11] \\
\hline \multirow[t]{2}{*}{ Root bark } & \multirow[t]{2}{*}{ Methanol } & $3 \mathrm{~L}, 3 \mathrm{M}, 4 \mathrm{~B}, 4 \mathrm{I}, 4 \mathrm{~K}, 5 \mathrm{~F}, 5 \mathrm{Y}$ & $\begin{array}{l}\text { At } 30 \mathrm{mg} / \mathrm{kg} \text {, only } 4 \mathrm{~B} \text { produced a } 22 \% \text { fall in the } \\
\qquad \text { MABP. }\end{array}$ & [18] \\
\hline & & $3 \mathrm{~A}, 4 \mathrm{~B}$ & 3A had higher antimicrobial potential than 4B. & [19] \\
\hline \multirow[t]{2}{*}{ Root-wood } & Methanol & $4 \mathrm{~B}, 4 \mathrm{~N}$ & $\begin{array}{l}\text { Both } 4 \mathrm{~B} \text { and } 4 \mathrm{~N} \text { found to have mild antimicrobial } \\
\text { activity. }\end{array}$ & [19] \\
\hline & Hexane & $3 \mathrm{~A}, 4 \mathrm{~A}$ & $\begin{array}{l}\text { Both } 3 \mathrm{~A} \text { and } 4 \mathrm{~A} \text { showed significant antimicrobial } \\
\text { activity as compared to nystatin and Dithane } \\
\qquad \mathrm{M}-45 \text {. }\end{array}$ & [26] \\
\hline \multirow[t]{2}{*}{ Seeds } & \multirow{2}{*}{ Methanol } & $3 \mathrm{~A}, 3 \mathrm{C}$ and $3 \mathrm{Q}, 4 \mathrm{~A}, 4 \mathrm{H}$ & $\begin{array}{l}3 \mathrm{~A}, 3 \mathrm{C} \text {, and } 3 \mathrm{Q} \text { were exhibited to be potent dual } \\
\text { inhibitors towards COX-1/2 and LOX enzymes }\end{array}$ & [42] \\
\hline & & $3 C, 3 Q$ & Both exhibited potent xanthine oxide inhibitory & [56] \\
\hline
\end{tabular}




\begin{tabular}{|c|c|c|c|c|}
\hline \multirow{2}{*}{ Stem } & Ethanol & $1 \mathrm{~F}, 5 \mathrm{~F}$ & $\begin{array}{l}\text { Only } 1 \mathrm{~F} \text { showed significant antibacterial activity } \\
\text { compared to amphicilin. }\end{array}$ & [9] \\
\hline & Methanol & $\begin{array}{c}\text { 1D:10 (1:2), } 1 \mathrm{P}-\mathrm{R}, 4 \mathrm{~A}, 40- \\
\quad \mathrm{R}, 5 \mathrm{M}, 5 \mathrm{AB}-\mathrm{AH}\end{array}$ & $\begin{array}{c}\text { Among all, 4A exhibited cytotoxicity against A549 } \\
\text { and MCF-7 cell lines. }\end{array}$ & [10] \\
\hline \multirow{4}{*}{ Stem bark } & Bioassay guided & $3 \mathrm{~A}, 4 \mathrm{~A}, 4 \mathrm{~B}$ & $\begin{array}{l}\text { 4A found to be most efficient in inhibition of } \\
\text { crown gall tumours. }\end{array}$ & [27] \\
\hline & Ethanol & $1 \mathrm{~A}, 2 \mathrm{~B}, 2 \mathrm{C}$ & - & [6] \\
\hline & Hexane & $3 \mathrm{~A}, 3 \mathrm{C}-\mathrm{H}, 4 \mathrm{~A}-\mathrm{G}$ & - & [16] \\
\hline & Petroleum ether & $4 A-B, 31$ & $\begin{array}{l}\text { All showed significant antibacterial activity } \\
\text { compared to kanamycin. }\end{array}$ & [17] \\
\hline Stem parts & Methanol & $5 \mathrm{E}, 5 \mathrm{~F}, 5 \mathrm{I}-\mathrm{L}$ & Among all, only 5F showed potent cytotoxicity. & [29] \\
\hline Unripe fruit & Methanol & $\begin{array}{c}3 \mathrm{~A}, 3 \mathrm{C}, 3 \mathrm{~J}, 3 \mathrm{~T}, 4 \mathrm{~A}, 4 \mathrm{~N}, \\
4 \mathrm{~T}-\mathrm{U}\end{array}$ & $\begin{array}{c}\text { At } 10 \mu \mathrm{m} \text {, compounds } 3 \mathrm{~A} \text { and } 4 \mathrm{~A} \text { exhibited } \\
\text { promising NO inhibitory activity. }\end{array}$ & [22] \\
\hline
\end{tabular}

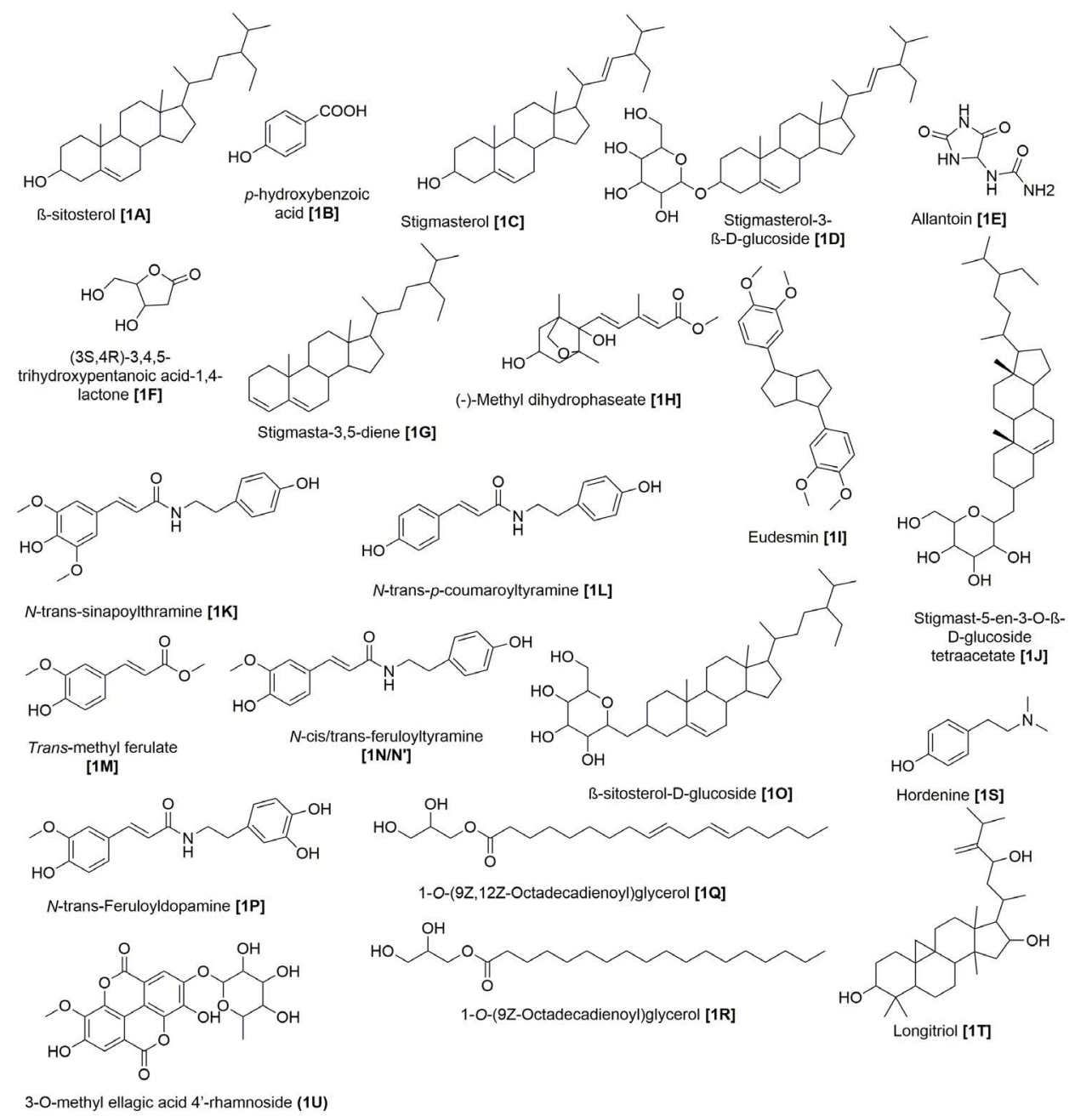

Fig. 2: Steroids and miscellaneous secondary metabolites reported from $P$. longifolia

(Table 1). These compounds have been noted for their antifeedant $^{[24]}$, antioxidant ${ }^{[25]}$, antibiotic ${ }^{[19,20,26]}$ and anticancer activities $^{[8,21,27]}$.

Lastly, 35 alkaloids have also been isolated while exploiting different parts of this plant (fig. 6). Among those, $5 \mathrm{~F}$ was repeatedly found in various parts of the plant ${ }^{[7,12,18,20,28,29]}$. Bioactivity studies of these alkaloid compounds revealed the cytotoxicity properties of $5 \mathrm{~F}^{[29]}, 5 \mathrm{~A}$ and $5 \mathrm{G}^{[7]}$ and the antibacterial capacities of $5 \mathrm{~V}, 5 \mathrm{~W}$ and $5 \mathrm{X}^{[11]}$. 

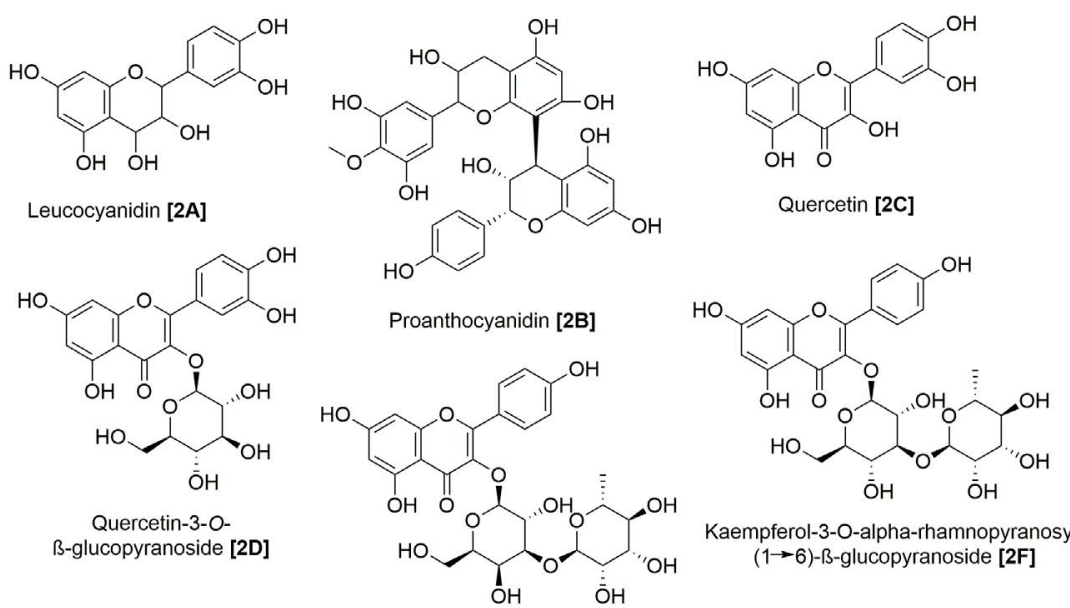

Kaempferol-3-O-alpha-rhamnopyranosylB-glucopyranoside [2D]

$(1 \rightarrow 6)$ - $\beta$-glucopyranoside [2F]

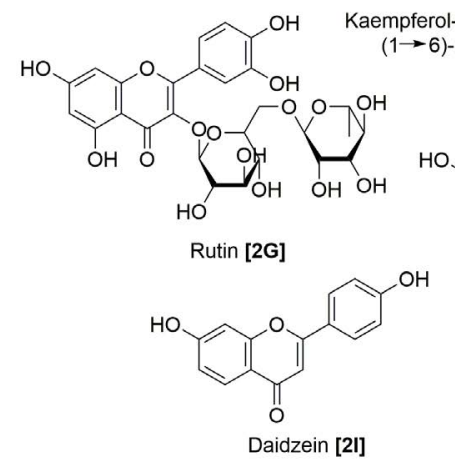

Fig. 3: Flavonoids reported from $P$. longifolia

\section{ANTIMICROBIAL ACTIVITY}

Bioassay of the metabolites isolated from P. longifolia extracts has revealed several with strong antibacterial activity, including $1 \mathrm{~F}^{[9]}, 2 \mathrm{G}^{[14]}, 3 \mathrm{~A}^{[19,20,26]}, 4 \mathrm{~A}^{[17,26]}, 5 \mathrm{~V}$, $5 \mathrm{~W}$ and $5 \mathrm{X}^{[11]}$.

Rashid et $a l^{[17]}$ performed an isolation work on the petroleum ether extract of $P$. longifolia stem bark and discovered 3 metabolites comprising 2 cleroda (4A and 4B) and a clerodane diterpene (3I). The total extract and metabolites were then tested for their antibacterial activities against 7 gram-positive $\left(\mathrm{Gram}^{+\mathrm{ve}}\right)$ and 12 gram-negative $\left(\mathrm{Gram}^{-\mathrm{ve}}\right)$ bacterial strains and 7 fungal strains and it was found that both the extract and those metabolites had significant antimicrobial activity. Among the 3 compounds, 4A had the highest activity against most of the tested microorganisms and had better inhibition potential as compared to kanamycin on several strains; diterpene 3I had the highest activity against Bacillus polymyxa and Shigella shiga and 4B was found to be the least active ${ }^{[17]}$.

Murthy et $a .^{[26]}$ analyzed the extract of seeds and found 2 metabolites, 3A and 4A. Antibacterial and antifungal activities of $3 \mathrm{~A}$ and $4 \mathrm{~A}$ were checked for $9 \mathrm{Gram}^{+\mathrm{ve}}$ and $7 \mathrm{Gram}^{\text {-ve }}$ bacterial strains and 8 fungal strains using the two fold serial dilution method and the paper disc method, respectively. Similar to the previous study, this study also revealed significant antibacterial activity of 4A. Moreover, 4A has the ability to act against fungi Candida and Saccharomyces with comparable potency as compared to the standard fungicides dithane M-45 and nystatins, respectively. On the other hand, $3 \mathrm{~A}$ was found to be highly active against most Gram ${ }^{\text {-ve }}$ bacteria, such as Escherichia coli (E. coli), Klebsiella aerogenes, Pseudomonas species and Sarcina lutea and one $\mathrm{Gram}^{+\mathrm{ve}}$ species (Bacillus) for which it showed a stronger effect than standard gentamycin ${ }^{[26]}$.

The antibacterial activity of $3 \mathrm{~A}$ and/or $4 \mathrm{~A}$ has also been reported by several later studies ${ }^{[19,20]}$. Specifically, Faizi et al. ${ }^{[11]}$ isolated 10 metabolites $(1 \mathrm{E}, 3 \mathrm{~A}, 3 \mathrm{~K}, 3 \mathrm{O}$, $3 \mathrm{P}, 4 \mathrm{~A}, 4 \mathrm{~B}, 4 \mathrm{~L}, 4 \mathrm{~N}$ and $4 \mathrm{O}$ ) from methanolic extracts of different parts of $P$. longifolia ${ }^{[30-34]}$ and tested them for antifungal and antibacterial potential against 11 fungal and 21 bacterial strains, using the disc diffusion technique. Among those, 5 clerodanes $(3 \mathrm{~A}, 4 \mathrm{~A}, 3 \mathrm{~K}$, $3 \mathrm{O}$ and $3 \mathrm{P}$ ) were found to be bioactive antimicrobial compounds and $3 \mathrm{~A}$ emerged as the best one ${ }^{[19]}$. Later, Gupta et al. successfully isolated 7 metabolites (3A, $3 \mathrm{~K}, 3 \mathrm{P}, 4 \mathrm{~A}, 4 \mathrm{I}, 4 \mathrm{~J}$ and $4 \mathrm{~S}$ ) from this variant. All these metabolites were tested against 6 fungal and 4 bacterial 
www.ijpsonline.com

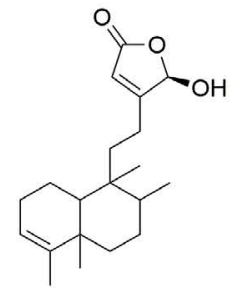

16a-Hydroxycleroda-3,13(14)Z-dien15,16-olide [3A]

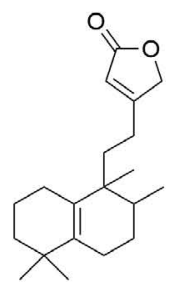

Ent-halima-5(10),13dien-16,15-olide [3F]

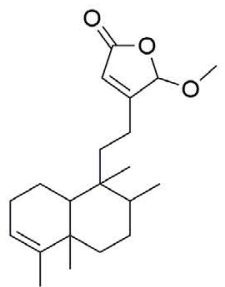

16a-Methoxycleroda-3,13Z-dien16,15-olide [3B]

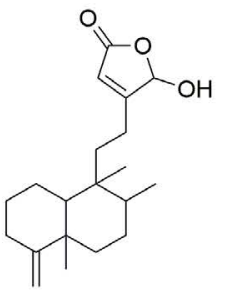

16-Hydroxycleroda-4(18),13-dien16,15-olide [3C]

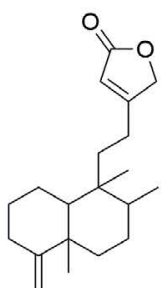

Cleroda-4(18), 13 dien-16,15-olide [3D]

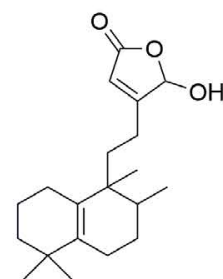

16-Hydroxy-enthalima-5(10),13-dien-

16,15-olide [3E]

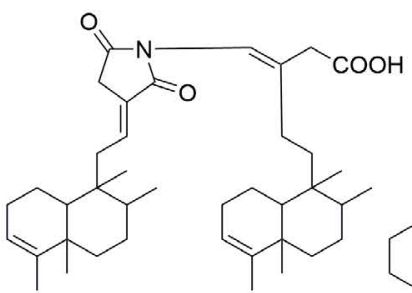

Bisclerodane imide (Longimide B) [3L]

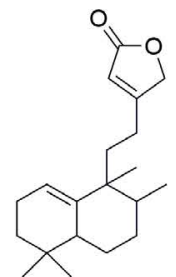

Ent-halima-1(10),13dien-16,15-olide [3G]
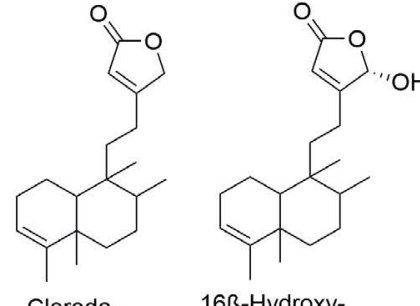
$3,13 Z$ cleroda-3,13(14)Zdiendien-15,16-olide [3I] 16,15-olide [3H]

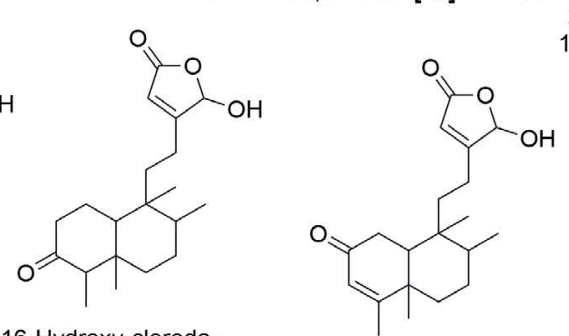
16-Hydroxy-cleroda-
13-ene-15,16-

16(R\&S)-3,13Z-Kolavadien-15,16olide-2-one [30]<smiles>C=C1[C@H](O)CCC2C1(C)CCC(C)C2(C)CCC1=CC(=O)OC1O</smiles>

3a,16a-Dihydroxycleroda-4(18), 13(14)Z -dien-15,16- olide [3Q]<smiles>CC1=CCCC2C1(C)CCC(C)C2(C)CCC1=CC(=O)N(/C=C(/CCC2(C)C(C)CCC3(C)C(C)=CCCC32)CC(=O)O)C1=O</smiles>

Longimide A [3R]<smiles>CC1=CCCC2C1(C)CCC(C)C2(C)CCC1=CC(=O)NC1=O</smiles>

Cleroda-3-ene-pyrrole15,16-dione (3U)

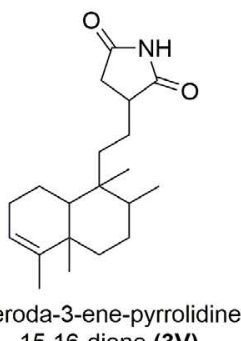

15,16-dione (3V)
$\mathrm{OH}$<smiles>CC1CCC2(O)C(CCC(O)C2(C)C)C1(C)CCC1=CC(=O)OC1O</smiles><smiles>[CH-]O</smiles>

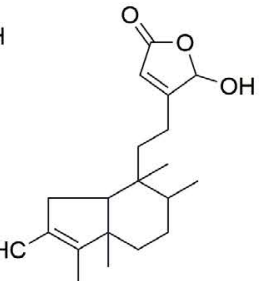

$4 \rightarrow 2$ )-Abeo-16(R and S) 2,13Z-kolava-dien15,16-olide-3-al [3K] olide-3-one [3N]

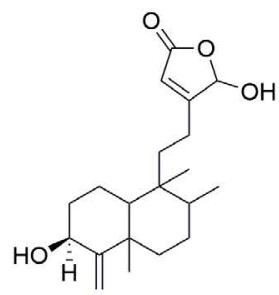

3ß,16a-Dihydroxycleroda-4(18), 13(14)Z O- $\quad$-dien-15,16- olide [3P]

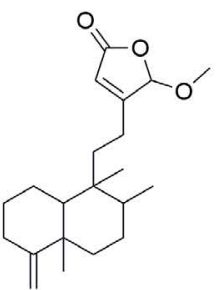

$\mathrm{HO}$<smiles>CC1(CO)C(O)CCC2(C)C(CC=C(C=O)CO)C3(CCC12C)CO3</smiles>

(Z)-4-Hydroxy-3-(2-(6-hydroxy-5-(hydroxymethyl)5,8a-dimethyloctahydro-1 $H$-spiro[naphthalene2,2'-oxiran]-1-yl)ethylidene)dihydrofuran-2(3H)-one [3S] R\&S)-Methoxycleroda-4(18),13-dien15,16-olide [3T]

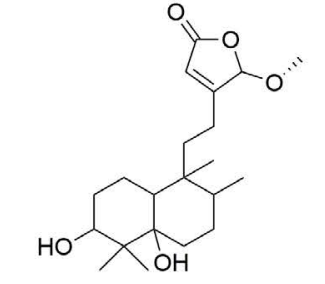

3ß,5ß-dihydroxy-16ß-methoxyhalima-13Z-en-15,16-olide [3Y]

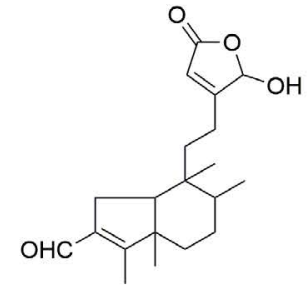

Polylongifoliaic A (3W)

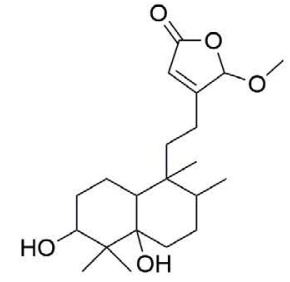

$3 ß, 5 ß$-dihydroxy-16a-methoxyhalima-13Z-en-15,16-olide [3X]

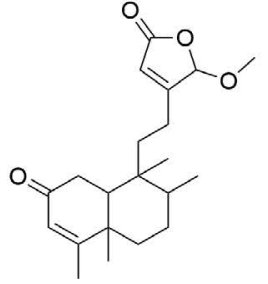

Polylongifoliaon A (3Z)

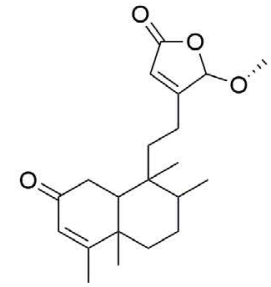

Polylongifoliaon B (3AA)

Fig. 4: Clerodane diterpenes reported from $P$. longifolia 
www.ijpsonline.com

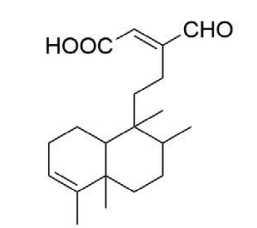

Polyalthialdoic acid (16-oxo-cleroda3,13(14)E-dien-15-oic acid) [4A]

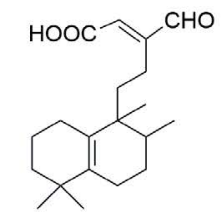

16-Oxo-ent-halima5(10),13E-dien15-oic acid [4F]

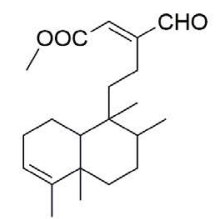

16-Oxo-cleroda3,13(14)E-dien15-oic acid methyl ester [4L]

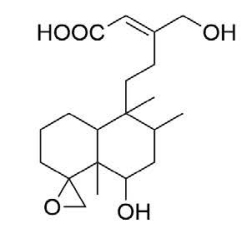

4a,18ß-Epoxy16-hydroxyclerod13-en-15-oic acid [4R]

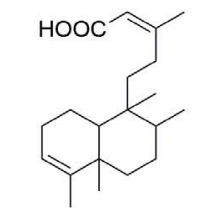

Kolavenic acid (Cleroda-3,13Edien-15-oic acid) [4B]

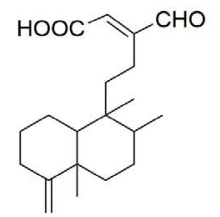

16-Oxo-cleroda4(18), 13E-dien15-oic acid [4C]

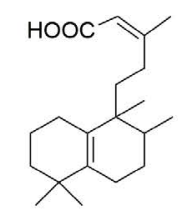

Ent-halima-5(10), 13Edien-15-oic acid [4D]

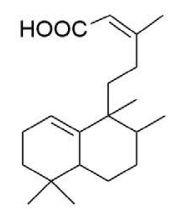

Ent-halima-1(10),13Edien-15-oic acid [4E]

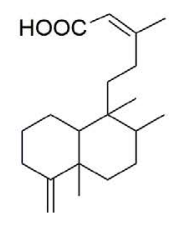

Cleroda-4(18),13Edien-15-oic acid [4G]

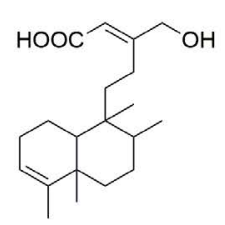

16-Hydroxy-cleroda3,13-dien-15oic acid [4H]

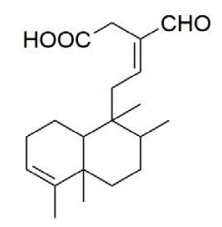

(-)-3,12E-Kolavadien-15-oic acid-16-al [4I]

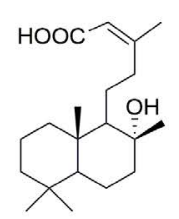

Labd-13E-en-8-ol15-oic acid [4J]

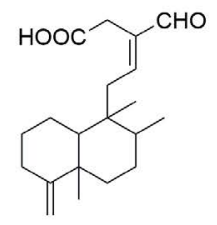

4(18), 12E-Kolavadien-15-oic acid-16-al [4K]
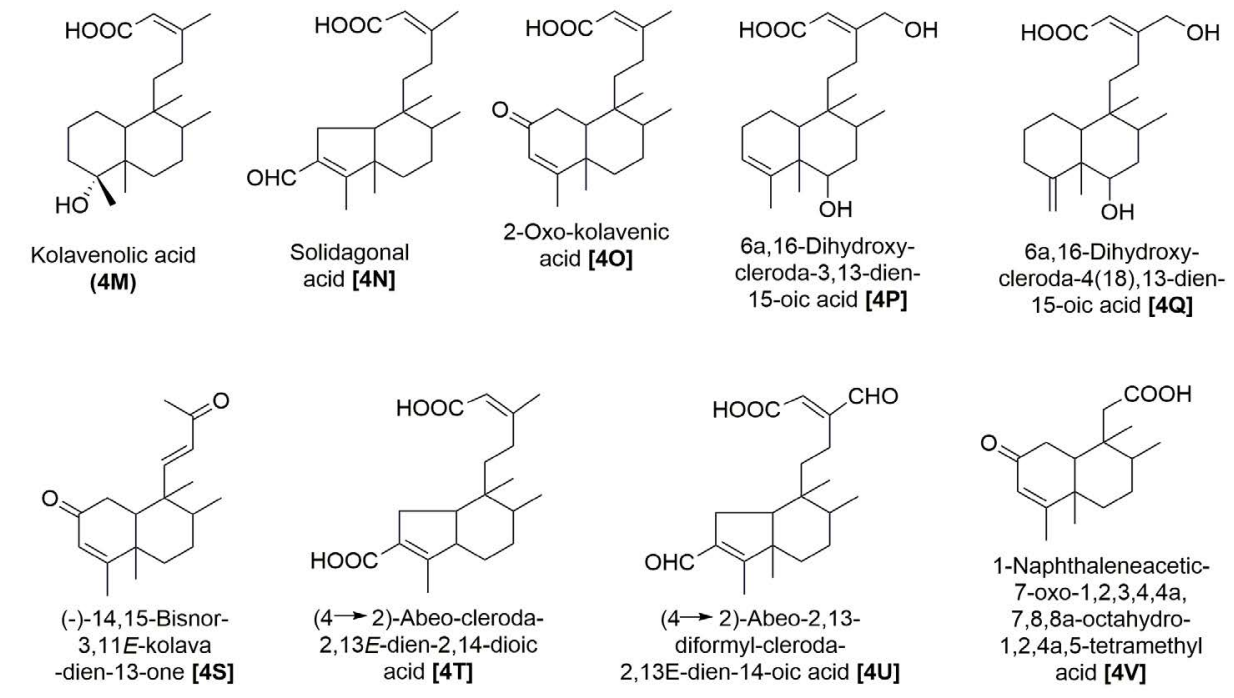

Fig. 5: Cleroda-oic acids reported from $P$. longifolia

strains and most of the tested compounds were found to be active against $E$. coli. Of those, diterpene $3 \mathrm{~A}$ was most active against Staphylococcus aureus (S. aureus) and fungi Sporothrix schenckii.

Additionally, in vitro and in vivo assays revealed 3A's ability to work against methicillin-resistant $S$. aureus with a minimum inhibitory concentration (MIC) of $15.625-31.25 \mathrm{mg} / \mathrm{l}$; while the MICs were significantly lower for the reference and clinical isolated strains of $S$. aureus. The combination of $3 \mathrm{~A}$ with $7.5 \%$ sodium chloride $(\mathrm{NaCl})$ caused a significant decrease in microbial count within $24 \mathrm{~h}$, signifying the loss of the salt tolerance capacity of $S$. aureus. Furthermore, application of $3 \mathrm{~A}$ in infected mice significantly dropped the systemic microbial load in spleen, liver, lung, blood and kidney tissues and it did not show any significant toxicity at $100 \mathrm{mg} / \mathrm{kg}$ dose ${ }^{[33]}$. Bhattacharya et al..$^{[35]}$ obtained metabolite $3 \mathrm{~A}$ from methanolic extract of $P$. longifolia leaves and reported its antifungal activity against Cryptococcus neoformans (a human pathogen), Candida albicans and Neurospora crassa (saprophyte ${ }^{[35]}$. The mechanism of action of $3 \mathrm{~A}$ in C. albicans was suggested to be compromised cell membrane permeability and/or cell wall structures or reactive oxygen species (ROS) generation as antifungal mechanisms ${ }^{[35]}$. Zhang et al. ${ }^{[36]}$ isolated $3 \mathrm{~A}, 4 \mathrm{~A}$ and 4B from stem bark extracts of $P$. longifolia and tested for antibacterial activity against methicillin-resistant Staphylococcus aureus and S. aureus. Of these, 4B was reported to have better activity than $3 \mathrm{~A}^{[36]}$.

Faizi et al. ${ }^{[19]}$ analyzed an ethanolic extract of stems of $P$. longifolia and the obtained metabolite $1 \mathrm{~F}$. This metabolite was tested for its antibacterial, antifungal, anti-mycobacterial and anticandidal activities using the disc diffusion method and was reported for its weak activity against these organisms ${ }^{[11]}$. Contemporaneously, 
<smiles>COc1ccc2c(c1O)-c1nccc(C)c1C2O</smiles>

Polylongine (5-hydroxy6-methoxy-1-methyl4-azafluoren-9-ol) [5A]

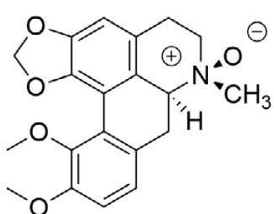

(+)-O-Methylbulbocapnine-

$\mathrm{B}-\mathrm{N}$-oxide [5B]

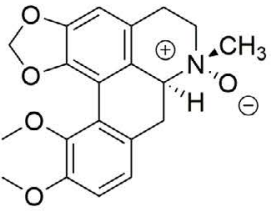

(+)-O-Methylbulbocapninealpha- $N$-oxide [5C]

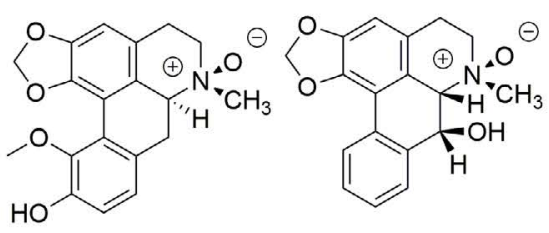

(+)-N-Methylnandigerine $-\beta-N$-oxide [5D]

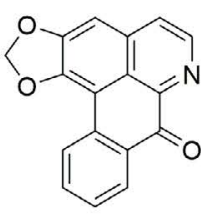

(-)-Oliveroline$\mathrm{B}-\mathrm{N}$-oxide [5E]<smiles>O[C@H]1c2ccccc2-c2c3c(cc4c2[C@@H]1NCC4)OCO3</smiles>

Noroliveroline [51]<smiles>COc1c(O)cc2c(c1OC)-c1nccc(C)c1C2=O</smiles>

Darienine [5J]<smiles>COc1cc2c(cc1OC)-c1nccc(C)c1C2=O</smiles>

Polyfothine [5K]<smiles>COc1cc2c(cc1O)C(=O)c1c(C)ccnc1-2</smiles>

Isooncodine [5L]

(+)-Norlirioferin [5H]<smiles>COc1cc2c(cc1O)-c1nccc(C)c1C2=O</smiles>

6-Hydroxy-7-methoxyonychine [50]<smiles>COC1=CC2CC3c4cc(O)c(OC)cc4C3C2=CC1=O</smiles>

(-)-Norpallidine [5P]

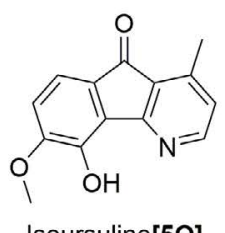

Isoursuline[5Q]

(-)-8-Oxopolyalthiaine [5M] 1,2-dihydro-9,10anthracenedione [5N]<smiles>COc1cc2c(cc1O)C1Cc3ccc(O)c(OC)c3CN1CC2</smiles>

(-)-Stepholidine [5R]<smiles>COc1ccc2c(c1)-c1c3c(cc4ccnc-2c4c1=O)OCO3</smiles>

Oxoxylopine [5S]<smiles>COc1c(O)cc2c3c1-c1ccccc1C[C@H]3NCC2</smiles>

(-)-Asimilobine [5T]<smiles>COc1cc2c(cc1O)CC1NCCc3cc(O)c(OC)c-2c31</smiles>

(士)-Norboldine (5U/U')

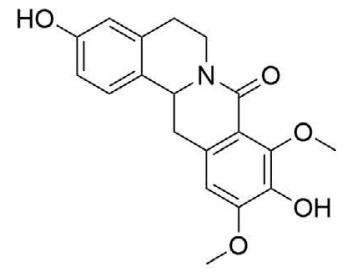

Pendulamine A [5V]<smiles>COc1cc2cc3n(c(=O)c2c(OC)c1O)CCc1cc(O)ccc1-3</smiles>

Pendulamine B [5W]<smiles>COc1ccc(C2Cc3ccc(O)c(OC)c3C(=O)N2C)cc1OC</smiles>

(-)-8-Oxo-10-hydroxy-2,3,9trimethoxyberberine [5AB]<smiles>O=C1c2ccccc2CC2c3ccccc3CCN12</smiles>

(-)-8-Oxotetrahydroplamatine [5AF]<smiles>COc1c(O)c(O)cc2c1C(=O)c1c(C)ccnc1-2</smiles><smiles>COc1cc2ccnc3c2c(c1OC)-c1ccccc1C3=O</smiles>

Lysicamine [5Y]<smiles>COC1=CC23C(=CC1=O)CCC2(C)c1cc(OC)c(O)cc13</smiles>

(-)-Pallidine [5Z]<smiles>COc1cc(C)c2c(c1OC)C1(C=CC(=O)C=C1)CC2N</smiles>

(+)-Stepharine [5AA]<smiles>COc1cc2c(cc1O)CC1c3cc(O)c(C)cc3CCN1C2=O</smiles>

(-)-8-Oxo-2,11-dihydroxy3,10-dimethoxyberberine [5AC]<smiles>COc1cc2c(cc1OC)C1Cc3ccc(O)c(O)c3C(=O)N1CC2</smiles>

(-)-8-Oxo-9,10-dihydroxy2,3-dimethoxyberberine [5AG]<smiles>COc1ccc(C2Cc3cc(O)c(OC)c(OC)c3C(=O)N2C)cc1OC</smiles>

(-)-8-Oxo-11-hydroxy-

2,3,9,10-tetramethoxy berberine [5AD]<smiles>COc1cc2c(cc1OC)C1Cc3cc(O)cc(OC)c3C(=O)N1CC2</smiles>

(-)-8-Oxo-11-hydroxy-2,3,9trimethoxyberberine [5AH]<smiles>COc1cc2c(cc1O)C1Cc3cc(OC)c(O)c(OC)c3C(=O)N1CC2</smiles>

(-)-8-Oxo-2,10-dihydroxy3,9,11-trimethoxyberberine [5AE]<smiles>COc1cc2c(cc1O)-c1c(cc(OC)c(O)c1O)C2=O</smiles>

(+)-Isoboldine [5Al]

Fig. 6: Alkaloids reported from $P$. longifolia 
this group investigated the antibacterial activity of petroleum ether and methanolic extract of roots of P. longifolia and its metabolites $(5 \mathrm{~V}, 5 \mathrm{~W}$ and $5 \mathrm{X})$ and showed that methanolic extract had better antibacterial activity as compared to petroleum ether extract and $5 \mathrm{~V}$ and $5 \mathrm{~W}$ were more active than $5 \mathrm{X}^{[9]}$. Jain et al. ${ }^{[37]}$ isolated $1 \mathrm{U}$ from a butanol fraction of $P$. longifolia stem bark and both were tested against aerobic bacterial strains. $1 \mathrm{U}$ exhibited higher antibacterial potential than the butanol fraction against almost all examined bacterial strains, but the potency was lower compared to standards (erythromycin, vancomycin, oxacillin and ciprofloxacin $)^{[37]}$.

Later, two flavonoids (F1 and F2, names not mentioned) were isolated from the ethanolic extract of bark of $P$. longifolia and reported for their antimicrobial and antifungal activities. F1 showed a strong inhibition against $B$. subtilis and a moderate inhibition against E. coli, B. thuringiensis and P. aeruginosa; whereas F2 showed moderate activity against E. coli, B. thuringiensis, B. subtilis and P. aeruginosa ${ }^{[38]}$.

Multiple extracts of different parts of $P$. longifolia were also tested for their antimicrobial activity. Accordingly, the petroleum ether extract was displayed to be more effective in antimicrobial activity than other solvent extracts $^{[39,40]}$.

\section{ANTI-INFLAMMATORY ACTIVITY}

Several studies have investigated the anti-inflammatory activity of compounds isolated from extracts of $P$. longifolia and found 2 clerodane diterpenes (3A and $3 \mathrm{~K}$ ) and 3 cleroda-oic acids $(4 \mathrm{~A}, 4 \mathrm{~L}, 4 \mathrm{H})$ to be active. $4 \mathrm{~L}$ and $3 \mathrm{~K}$ were the first compounds isolated from this plant to be reported for inhibitory activity against formyl-L-methionyl-L-leucyl L-phenylalanine/ cytochalasin B (fMLP/CB)-induced superoxide generation by neutrophils ${ }^{[12]}$. After that, Chang et al..$^{[12]}$ established the anti-inflammatory functions of $4 \mathrm{H}$ in isolated human neutrophils. $4 \mathrm{H}$ induced the discharge of elastase in fMLP-activated human neutrophils in a concentration-dependent mode. Its suppressive effects on degranulation and human neutrophil respiratory burst were at least partly facilitated by inhibition of protein kinase $\mathrm{B}(\mathrm{PKB} / \mathrm{AKT})$, calcium and p38 signaling pathway ${ }^{[25]}$. Later, Wu et al..$^{[28]}$ isolated and investigated the inhibitory effect of $3 \mathrm{~A}$ and $4 \mathrm{~A}$ on nitric oxide production in lipopolysaccharide (LPS)-stimulated macrophage (RAW 264.7) cells by the Griess reaction and half maximal inhibitory concentration $\left(\mathrm{IC}_{50}\right)$ values of $3 \mathrm{~A}$ and $4 \mathrm{~A}$ were found to be $\sim 1 \mu \mathrm{m}^{[22]}$. Similarly,
Shih et al. found that $3 \mathrm{~A}$ reduced the expression of cyclooxygenase 2 (COX-2), inducible nitric oxide synthase (iNOS), nuclear factor kappa-light-chainenhancer of activated B cells protein $65(\mathrm{NF}-\kappa \mathrm{Bp} 65)$ and a glycosylated 91-kDa glycoprotein (gp91 ${ }^{\text {phox }}$ ), while it boosted the expression of $\mathrm{HO}^{-1}$, an anti-inflammatory and cytoprotective enzyme. Moreover, 3A reduced LPS-activated microglia-induced cell death, suggesting $3 \mathrm{~A}$ as a potential candidate to treat inflammation related to microglia and neuronal cell death ${ }^{[41]}$.

More recently, our group identified five clerodane diterpenes (3A, 3C, 3Q, 4A and 4H) from methanolic extract of seeds of $P$. longifolia and reported on their anti-inflammatory activities. Of these, compounds $3 \mathrm{~A}$, $3 \mathrm{C}$ and $3 \mathrm{Q}$ were exhibited to be potent dual inhibitors towards COX-1/2 and lipoxygenases (LOX) enzymes with $\mathrm{IC}_{50}$ values lower than or similar to those of the indomethacin and allopurino ${ }^{[42]}$.

\section{CYTOTOXICITY}

Several compounds isolated from this plant have also been tested for their cytotoxicity and a few of them, including 3A and 4A, have been repeatedly reported for their anti-cancer properties. Wu et al. ${ }^{[43]}$ investigated the bioassay-guided isolation of methanolic extract of $P$. longifolia stem parts using the KB cytotoxicity assay. Specifically, metabolite $5 \mathrm{~F}$ obtained from this extract demonstrated great potential cytotoxicity against adenocarcinomic human alveolar basal epithelial cell (A549), tebu-bio's knockdown (KB), human cancer cell lines (HCT-8), mouse lymphocytic leukemia cell line (L-1210) and leukemia cell (P-388) cells ${ }^{[29]}$. In another study, 3 metabolites (3A, 4A and 4B) obtained from stem bark of $P$. longifolia were tested for cytotoxicity by brine shrimp bioassay. These compounds were found to have a strong anti-growth capacity against crown gall tumors (A-549, MCF-7 and HT-29) on potato discs ${ }^{[27]}$.

Later, Chen et al. ${ }^{[29]}$ assessed the petroleum ether extract of leaves of $P$. longifolia and reported that several of the isolated compounds (3A, 5A and $5 \mathrm{G}$ ) were highly active against different cancer cell lines via 3-(4,5-dimethylthiazol-2-yl)-2,5-diphenyltetrazolium bromide, a tetrazole (MTT) assay. Particularly, 5A was active against Hepatoma cell line (HA59T) while $3 \mathrm{~A}$ and $5 \mathrm{G}$ displayed significant cytotoxicity against adenocarcinoma gastric cell line (AGS) and HA59T and AGS, Colorectal Adenocarcinoma cell line (DLD1), human hepatoma cell lines (HepG2) and HA59T, respectively ${ }^{[7]}$. Similarly, another group isolated 13 metabolites $(1 \mathrm{~L}, 1 \mathrm{~N}$ ', 3A, 3C, 3K, 3O, 4L, 4N, 5A, 5F, 
5R, 5Y and 5AA). All these compounds were tested against breast cancer cell line (MCF-7) and an epithelial, human breast cancer cell line (MDA-MB-231), while $3 \mathrm{~A}, 3 \mathrm{C}, 3 \mathrm{O}, 4 \mathrm{~L}$ and $4 \mathrm{~J}$ were further tested on human hepatoma (Hep 3B and Hep G2) cell lines. Their results exposed significant inhibitory activity against Hep $3 \mathrm{~B}$ and Hep $\mathrm{G} 2$ of $3 \mathrm{~A}, 3 \mathrm{C}$ and $3 \mathrm{O}^{[12]}$. Misra et al. ${ }^{[30]}$. isolated 3 compounds $3 \mathrm{~A}, 3 \mathrm{P}$ and $3 \mathrm{Q}$. The activity of $3 \mathrm{~A}$ on J774A.1 macrophages was assessed by MTT reduction assay and no cytotoxic effect was found even at $200 \mathrm{mg} / \mathrm{ml}$ concentration ${ }^{[30]}$. Wu et al..$^{[43]}$ obtained 12 diterpenes $(3 \mathrm{~B}, 3 \mathrm{~K}, 3 \mathrm{O}, 3 \mathrm{P}, 3 \mathrm{Q}, 3 \mathrm{~W}, 3 \mathrm{X}, 3 \mathrm{Y}, 3 \mathrm{Z}, 3 \mathrm{AA}$, $4 \mathrm{O}$ and $4 \mathrm{~L}$ ) from the methanolic extract of unripe fruit of $P$. longifolia and tested for cell viability in human neuroblastoma (SKNMC) cells using amyloid-beta (A $\beta$ )-induced neurotoxicity. Of these, compounds 3P, $3 \mathrm{O}, 3 \mathrm{~W}, 3 \mathrm{AA}$ and $4 \mathrm{O}$ improved the ability of SKNMC cells. Among the active compounds, $3 \mathrm{~W}$ and $3 \mathrm{AA}$ revealed the most powerful activity toward SKNMC cells. Additionally, the isolated compounds were found to have strong acetylcholinesterase inhibitory actions in TLC bioautographic assay ${ }^{[43]}$.

In addition, several other compounds have been isolated and tested for their cytotoxicity on different cell lines ${ }^{[14,21,32]}$. 3P and 3Q were examined for their growth inhibitory actions on ovarian teratocarcinoma cell line (PA1), MCF-7, KB and cervical cancer cells (C33A) using MTT assay and both of them exhibited good inhibitory activity against C33A and PA1 and moderate inhibitory activity against the remaining cell lines. They have also been tested against Vero (African green monkey kidney) cell lines, in which 3Q was more active than $3 \mathrm{P}^{[21]}$. $2 \mathrm{G}$ was isolated from ethanolic extract of $P$. longifolia leaves and examined against A549 using MTT-based cytotoxicity activity and the cytotoxic concentration $\left(\mathrm{CTC}_{50}\right)$ values of ethanol extract, preparative thin layer chromatography (PTLC) isolate and $2 \mathrm{G}$ were found to be $210 \pm 5.14,230 \pm 10.62$ and $270 \pm 3.001 \mu \mathrm{g} / \mathrm{ml}$, respectively ${ }^{[14]}$.

Compounds 3A, 4A and 4B isolated from ethyl acetate extract of $P$. longifolia leaves were tested for cytotoxicity on promyelocytic cell line (HL-60) using MTT assay. The $\mathrm{IC}_{50}$ values of $3 \mathrm{~A}, 4 \mathrm{~A}$ and $4 \mathrm{~B}$ were reported to be $25.0,12.5$ and $6.25 \mu \mathrm{m}$, respectively ${ }^{[32]}$. Compound $3 \mathrm{~A}$ exhibited a potential effect on cell viability on mouse neuroblastoma $(\mathrm{N} 18)$ and rat glioma (C6) cell lines by MTT assay and cell cycle arrest in the resting phase-growth 1 phase $\left(\mathrm{G}_{0}-\mathrm{G}_{1}\right)$ phase. Treatment with compound $3 \mathrm{~A}$ raised pro-apoptotic proteins and reduced anti-apoptotic proteins ${ }^{[44]}$. The involvement of
3A-induced autophagy in N18 and C6 via activation of active extracellular-signal-regulated kinase $1 / 2$ (pERK $1 / 2$ ) and phosphorylated-p38 mitogen-activated protein kinase expression (P-p38 MAPK) pathway has also been studied. It was found that $3 \mathrm{~A}$ significantly induced p-ERK-1/2 and P-p38 MAPK proteins, implying that $3 \mathrm{~A}$ acts as a potential anticancer compound that employs its action via inducing ROS-mediation ${ }^{[45]}$. The $\mathrm{IC}_{50}$ values of compounds $4 \mathrm{~V}$ and $3 \mathrm{~A}$ isolated from ethyl acetate fraction of $P$. longifolia leaves were 71.1 and $44.8 \mu \mathrm{m}$, respectively ${ }^{[46]}$. Multiple compounds (1D:1O (1:2), 1P-R, 4A, 4O-R, 5M and 5AB-AH) have also been successfully isolated by Lee et al. ${ }^{[11]}$, but among those, only 4A exhibited cytotoxicity against A549 and MCF-7 cancer cells ${ }^{[10]}$.

Recently, Liu et al. investigated the antitumor activity of $3 \mathrm{~A}$ in two human clear-cell type renal (7860 and A498) carcinoma lines and stated that $3 \mathrm{~A}$ induced cell necrosis via ROS overproduction ${ }^{[47]}$. Also, Chen et al. ${ }^{[48]}$ investigated the governing mechanisms of $3 \mathrm{~A}$-induced programmed cell death in $786 \mathrm{O}$ and A498 cells and reported that $3 \mathrm{~A}$-induced cell phase arrest, focal adhesion complex break down and the inactivation of signaling pathways (migratory-related) to prompt apoptosis $^{[48]}$.

In addition, two fractions (F1 and F2) were isolated from seed proteins of $P$. longifolia using trypsin. The MTT assay revealed a significant cytotoxicity of F2 against immortal cell line (HeLa) and A-549 cells at 30 and $10 \mu \mathrm{g} / \mathrm{ml}$, respectively. Further, flow cytometry analyses found that F2 augmented apoptotic cells in sub- $\mathrm{G}_{0}$ phase of HeLa and A549 at 30 and $10 \mu \mathrm{g} / \mathrm{ml}$, respectively. This suggested that $\mathrm{F} 2$ peptide is an active inducer of programmed cell death of cancer cells ${ }^{[49]}$.

\section{ANTIOXIDANT PROPERTIES}

The ability of $4 \mathrm{H}$ to scavenge $\mathrm{O}_{2}{ }^{--}$and free radicals was assayed using 2,2-diphenyl-1-picrylhydrazyl (DPPH) free radical scavenging test and cell-free xanthine oxidase system. Up to $10 \mu \mathrm{m}$ concentration, $4 \mathrm{H}$ failed to modify DPPH and water soluble tetrazolium salts-1 (WST-1) reduction, indicating that the inhibitory effect by $\mathrm{O}_{2}{ }^{--}$release shown by $4 \mathrm{H}$ occurs via scavenging of free radicals and $\mathrm{O}_{2}{ }^{-}$. In addition, $4 \mathrm{H}$ did not induce the elimination of $\mathrm{O}_{2}{ }^{-}$by superoxide dismutase $(0.5 \mathrm{U} / \mathrm{ml})$, meaning that $4 \mathrm{H}$ did not have superoxide anion-scavenging or antioxidant activity ${ }^{[25]}$. Sashidhara et al. isolated and tested three compounds 2C, 2D and $2 \mathrm{G}$ for scavenging of free radicals and reported that $2 \mathrm{C}$ had the highest antioxidant activity $(4.10 \mathrm{mM})$ of 
all, followed by $2 \mathrm{G}(2.38 \mathrm{mM})$ and $2 \mathrm{D}(1.91 \mathrm{mM})$ [13]. Additionally, $2 \mathrm{G}$ metabolite $\left(\mathrm{IC}_{50}\right.$ value $=14.67$ $\pm 0.023 \mu \mathrm{g} / \mathrm{ml}$ ) from the ethanolic extract of leaves of P. longifolia was reported for its antioxidant ability ${ }^{[14]}$.

Two flavonoids (F1 and F2) obtained from the ethanol (95\%) extract of bark of $P$. longifolia were tested for DPPH radical scavenging, nitric oxide scavenging, metal chelating and reducing power activities. The results showed that $\mathrm{F} 1$ had stronger antioxidant activity than $\mathrm{F}^{[38]}$. Chen et al. ${ }^{[43]}$ isolated $2 \mathrm{~J}$ from acetone extract of leaves of $P$. longifolia and reported DPPH, 2,2'-azino-bis(3-ethylbenzothiazoline-6-sulfonic acid (ABTS) and ferric ion reducing activities. The $\mathrm{IC}_{50}$ values were $89.32 \pm 12.07$ and $76.79 \pm 5.88 \mathrm{mg} / \mathrm{ml}$ against DPPH and ABTS free radicals respectively and the ferric ion reducing power value was 710.54 $\pm 142.82 \mathrm{mg}$ ascorbic acid equivalent/g dry weight ${ }^{[50]}$.

The compound $1 \mathrm{U}$ from butanol fraction of $P$. longifolia stem bark was also tested against DPPH free radicals by Jain et al. ${ }^{[37]}$. The highest antioxidant activity of $1 \mathrm{U}$ and butanol fraction was $57.95 \%$ and $66.05 \%$ respectively, at $40 \mu \mathrm{g} / \mathrm{ml}$. Accordingly, $1 \mathrm{U}$ exhibited better antioxidant properties than the standard drug, vitamin $\mathrm{C}^{[37]}$.

\section{MISCELLANEOUS ACTIVITIES}

Two isolated metabolites (3A and 4A) from acetone extract of leaves of $P$. longifolia were tested for their antifeedant activity against casterlooper i.e., Achara janata and antifeedant activity was noted in both of them $^{[24]}$.

Metabolites 3L, 3U and 3V were isolated from bark of $P$. longifolia and reported for their anti-plasmodial property with $\mathrm{IC}_{50}$ values ranging $1.51-3.37 \mu \mathrm{g} / \mathrm{ml}^{[51]}$. Gbedema et al.${ }^{[52]}$ identified $1 \mathrm{C}, 3 \mathrm{~A}, 3 \mathrm{Q}, 4 \mathrm{~A}, 5 \mathrm{~J}$ and $5 \mathrm{R}$ from steam barks of $P$. longifolia and tested for antiplasmodial activity using Plasmodium falciparum K1 strain. Among those, 3A, 3Q and 4A were found to have potent $\mathrm{IC}_{50}$ values ranging from 3-6 $\mu \mathrm{g} / \mathrm{ml}$, while others showed mild anti-plasmodial activity ${ }^{[52]}$.

Clerodane diterpene 3A from hexane extract of $P$. longifolia leaves was tested for in vitro and in vivo antileishmanial activities. The antileishmanial activity of $3 \mathrm{~A}$ ( $\mathrm{IC}_{50}$ value: $5.79 \pm 0.31 \mu \mathrm{g} / \mathrm{ml}$ ) was found to be similar to that of the standard drug (miltefosine, $5 \mu \mathrm{g} / \mathrm{ml}$ ). At $250 \mathrm{mg} / \mathrm{kg}$ dose, a higher efficacy of $3 \mathrm{~A}$ administere by the oral route was observed in the liver $(87.5 \pm 1.8 \%)$, bone marrow $(89.1 \pm 2.1 \%)$ and spleen $(91 \pm 2 \%)$; while at $100 \mathrm{mg} / \mathrm{kg}$, the percentages of inhibition were found to be $86.88 \pm 1.3,83.7 \pm 1.5$ and $84.2 \pm 2.2 \%$, respectively ${ }^{[30]}$. Similarly, Zhang group tested 3A, 4A and 4B isolated from P. longifolia stem bark extract for their antileishmanial activity against Leishmania donovani (L. donovani) axenic amastigote, $L$. donovani amastigote and $L$. donovani promastigote in human acute monocytic leukemia cell line (THP-1) macrophage cultures. Among all of these, only $3 \mathrm{~A}$ was reported to have activity, with $\mathrm{IC}_{50}$ values of $<1.60$, 2.34 and $4.50 \mu \mathrm{g} / \mathrm{ml}$, respectively ${ }^{[36]}$.

Amongst 7 isolated compounds (4A, 4B, 4C, 3L, $3 \mathrm{M}, 5 \mathrm{~F}$ and $5 \mathrm{Y}$ ) of defatted extract of root bark of P. longifolia in methanol (50\%), 4B (30 mg/ $\mathrm{kg}$ dose) was claimed to be the one that confers hypotensive activity as it caused a $22 \%$ reduction in the mean arterial blood pressure ${ }^{[18]}$.

$3 \mathrm{~A}$ and $3 \mathrm{~K}$ were isolated from methyl chloride $\left(\mathrm{CH}_{3} \mathrm{Cl}\right)$ soluble fraction from $70 \%$ hydroalcoholic extract of leaves of $P$. longifolia and tested for antihistaminic activity. 3A ( IC $_{50}$ value of $29.7 \mu \mathrm{g} / \mathrm{ml}$ ) showed a dosedependent inhibition of histamine discharge, while $3 \mathrm{~K}$ $\left(\mathrm{IC}_{50}=189.2 \mu \mathrm{g} / \mathrm{ml}\right)$ showed very weak activity ${ }^{[53]}$.

The two metabolites $3 \mathrm{~A}$ and $3 \mathrm{~K}$ were also tested for anti-helicobacter property against $H$. pylori and it was found that $3 \mathrm{~A}$ completely inhibited the growth of $H$. pylori with $\mathrm{MIC}$ of $31.25 \mu \mathrm{g} / \mathrm{ml}$. $3 \mathrm{~K}$ (MIC value $>125 \mu \mathrm{g} / \mathrm{ml}$ ), on the other hand, showed a weak inhibitory action ${ }^{[53]}$.

Four clerodane diterpenes (3A, 3K, 3P and 4A) were obtained from ethanolic extract of $P$. longifolia leaves and reported for their lipid lowering strength in the high fat diet hamster model, at $25 \mathrm{mg} / \mathrm{kg}$ dose. Among these 4 , only $3 \mathrm{~A}$ showed pronounced activity comparable to lovastatin, while others did not show any activity. The mechanistic studies of 3A "privileged structure" exposed that it inhibited the DNA topoisomerase I of L. donovani and proposed as a potential 3-hydroxy-3methyl-glutaryl-coenzyme A (HMG-CoA) reductase inhibitor $^{[31]}$.

Ebiloma et al.$^{[54]}$ isolated $3 \mathrm{~A}, 4 \mathrm{~A}$ and $4 \mathrm{~B}$ from the leaves of $P$. longifolia and tested for anti-trypanosomatid activity using Trypanosoma brucei (T. brucei) and $T$. congolense and promastigotes of L. mexicana. Among those, 3A was found to be more potent against the above pathogens, with half maximal effective concentration $\left(\mathrm{EC}_{50}\right.$ ) value of below $0.38 \mu \mathrm{g} / \mathrm{ml}^{[54]}$ and the mechanism of action of $3 \mathrm{~A}$ for anti-trypanosomatid activity was found to be multi-targeted ${ }^{[55]}$. Moreover, besides anti-oxidant activity, 2J obtained from acetone 
extract of leaves of $P$. longifolia also showed a potent antityrosinase activity with $\mathrm{IC}_{50}$ value of 773.09 $\pm 1.47 \mathrm{mg} / \mathrm{ml}^{[50]}$.

More recently, Nuygen group screened compounds 3C and 3Q for their xanthine oxidase inhibitory assay using both in vitro and in silico methods and found that both showed potent inhibitory activity against xanthine oxidase enzyme, compared to standard drug allopurinol ${ }^{[56]}$.

The broad and ongoing use of $P$. longifolia in a system of traditional medicine suggests its safety for human use at appropriate doses. This has been confirmed in the lab via toxicology studies of leaf extracts in Wistar albino rat $^{[57]}$. Moreover, treatment with leave extracts of $P$. longifolia reversed the adverse effects in the cadmium-induced tissues via increased antioxidant activity. This effect could partly due to a rich source of phenolic compounds and other effective antioxidants present in the leaf extract of this plant ${ }^{[1,13]}$.

\section{CONCLUSION}

Plants used in traditional systems of medicine have often been a starting point in the search for new and effective pharmaceuticals. This is partly because their history of human use suggests their safety and partly because a significant portion of traditional medicines have been shown to be effective. The investigations into $P$. longifolia summarized in this review have reinforced that it is worthy of further, more in-depth study in terms of potential drug discovery. Future research into $P$. longifolia and its extracts is needed to determine their degree of benefit in the treatment of specific conditions and their mechanisms of action.

\section{Acknowledgements:}

The authors sincerely thank the Department of Science and Technology (DST) for funding the project with the grant number (DST/DISHA/SoRF$\mathrm{PM} / 032 / 2015 / 01 / \mathrm{G})$.

\section{Conflict of interests:}

The author declares no conflict of interest.

\section{REFERENCES}

1. Katkar KV, Suthar AC, Chauhan VS. The chemistry, pharmacologic and therapeutic applications of Polyalthia longifolia. Pharmacogn Rev 2010;4(7):62-8.

2. Thang TD, Hoi TM, Ogunwande IA. Essential oil constituents of Desmos cochinchinensis Lour, and Polyalthia longifolia var. pendula Hort from Vietnam. Plant 2014;1(4):45-9.

3. Yao LJ, Jalil J, Attiq A, Hui CC, Zakaria NA. The medicinal uses, toxicities and anti-inflammatory activity of Polyalthia species (Annonaceae). J Ethnopharmacol 2019;229:303-25.

4. Paarakh PM, Khosa RL. Phytoconstituents from the genus Polyalthia-a review. J Pharm Res 2009;2(4):594-605.

5. Ghosh A, Das BK, Chatterjee SK, Chandra G. Antibacterial potentiality and phytochemical analysis of mature leaves of Polyalthia longifolia (Magnoliales: Annonaceae). South Pacific J Nat Appl Sci 2008;26(1):68-72.

6. Agrawal S, Misra K. Proanthocyanidin from Polyalthia longifolia stem bark. Curr Sci 1979;48:141-3.

7. Chen CY, Chang FR, Shih YC, Hsieh TJ, Chia YC, Tseng HY, et al. Cytotoxic constituents of Polyalthia longifolia var. pendula. J Nat Prod 2000;63(11):1475-8.

8. Sashidhara KV, Singh SP, Kant R, Maulik PR, Sarkar J, Kanojiya $\mathrm{S}$, et al. Cytotoxic cycloartane triterpene and rare isomeric bisclerodane diterpenes from the leaves of Polyalthia longifolia var. pendula. Bioorganic Med Chem Lett 2010;20(19):5767-71.

9. Faizi S, Mughal NR, Khan RA, Khan SA, Ahmad A, Bibi N, et al. Evaluation of the antimicrobial property of Polyalthia longifolia var. pendula: isolation of a lactone as the active antibacterial agent from the ethanol extract of the stem. Phyther Res 2003;17(10):1177-81.

10. Lee TH, Wang MJ, Chen PY, Wu TY, Wen WC, Tsai FY, et al. Constituents of Polyalthia longifolia var. pendula. J Nat Prod 2009;72(11):1960-3.

11. Faizi S, Khan RA, Azher S, Khan SA, Tauseef S, Ahmad A. New antimicrobial alkaloids from the roots of Polyalthia longifolia var. pendula. Planta Med 2003;69(04):350-5.

12. Chang FR, Hwang TL, Yang YL, Li CE, Wu CC, Issa HH, et al. Anti-inflammatory and cytotoxic diterpenes from formosan Polyalthia longifolia var. pendula. Planta Med 2006;72(14):1344-7.

13. Sashidhara KV, Singh SP, Srivastava A, Puri A. Identification of the antioxidant principles of Polyalthia longifolia var. pendula using TEAC assay. Nat Prod Res 2011;25(9):918-26.

14. Sampath M, Vasanthi M. Isolation, structural elucidation of flavonoids from Polyalthia longifolia (Sonn.) Thawaites and evaluation of antibacterial, antioxidant and anticancer potential. Int J Pharm Pharm Sci 2013;5(1):336-41.

15. Chakrabarty M, Nath AC. A new clerodane-type butenolide diterpene from the bark of Polyalthia longifolia. J Nat Prod 1992;55(2):256-8.

16. Hara N, Asaki H, Fujimoto Y, Gupta YK, Singh AK, Sahai M. Clerodane and ent-halimane diterpenes from Polyalthia longifolia. Phytochemistry 1995;38(1):189-94.

17. Rashid MA, Hossain MA, Hasan CM, Reza MS. Antimicrobial diterpenes from Polyalthia longifolia var. pendulla (Annonaceae). Phyther Res 1996;10(1):79-81.

18. Saleem R, Ahmed M, Ahmed SI, Azeem M, Khan RA, Rasool $\mathrm{N}$, et al. Hypotensive activity and toxicology of constituents from root bark of Polyalthia longifolia var. pendula. Phytother Res 2005;19(10):881-4.

19. Faizi S, Khan RA, Mughal NR, Malik MS, Sajjadi KE, Ahmad A. Antimicrobial activity of various parts of Polyalthia longifolia var. pendula: isolation of active principles from the leaves and the berries. Phytother Res 2008;22(7):907-12.

20. Sashidhara KV, Singh SP, Shukla PK. Antimicrobial evaluation of clerodane diterpenes from Polyalthia longifolia var. pendula. Nat Prod Commun 2009;4(3):1934578X0900400305.

21. Sashidhara KV, Singh SP, Sarkar J, Sinha S. Cytotoxic clerodane diterpenoids from the leaves of Polyalthia longifolia. Nat Prod Res 2010;24(18):1687-94. 
22. Wu TH, Cheng YY, Chen CJ, Ng LT, Chou LC, Huang LJ, et al. Three new clerodane diterpenes from Polyalthia longifolia var. pendula. Molecules 2014;19(2):2049-60.

23. Ghosh G, Subudhi BB, Banerjee M, Mishra SK. A new clerodane-type $\gamma$-hydroxybutenolide diterpene from the bark of Polyalthia longifolia var. angustifolia. Indian J Chem B 2011;50(10):1510-12.

24. Phadnis AP, Patwardhan SA, Dhaneshwar NN, Tavale SS, Row TN. Clerodane diterpenoids from Polyalthia longifolia. Phytochemistry 1988;27(9):2899-901.

25. Chang HL, Chang FR, Chen JS, Wang HP, Wu YH, Wang $\mathrm{CC}$, et al. Inhibitory effects of 16-hydroxycleroda-3, 13 (14) E-dien-15-oic acid on superoxide anion and elastase release in human neutrophils through multiple mechanisms. Eur J Pharmacol 2008;586(1-3):332-9.

26. Murthy MM, Subramanyam M, Bindu MH, Annapurna J. Antimicrobial activity of clerodane diterpenoids from Polyalthia longifolia seeds. Fitoterapia 2005;76(3-4):336-9.

27. Zhao G, Jung JH, Smith DL, Wood KV, McLaughlin JL. Cytotoxic clerodane diterpenes from Polyalthia longifolia. Planta Med 1991;57(04):380-3.

28. Wu YC. Azafluorene and aporphine alkaloids from Polyalthia longifolia. Heterocycles 1989;29(3):463-75.

29. Wu YC, Duh CY, Wang SK, Chen KS, Yang TH. Two new natural azafluorene alkaloids and a cytotoxic aporphine alkaloid from Polyalthia longifolia. J Nat Prod 1990;53(5):1327-31.

30. Misra P, Sashidhara KV, Singh SP, Kumar A, Gupta R, Chaudhaery SS, et al. 16a-Hydroxycleroda-3, 13 (14) Zdien-15, 16-olide from Polyalthia longifolia: a safe and orally active antileishmanial agent. Br J Pharmacol 2010;159(5):114350.

31. Sashidhara KV, Singh SP, Srivastava A, Puri A, Chhonker YS, Bhatta RS, et al. Discovery of a new class of HMG-CoA reductase inhibitor from Polyalthia longifolia as potential lipid lowering agent. Eur J Med Chem 2011;46(10):5206-11.

32. Sari DP, Ninomiya M, Efdi M, Santoni A, Ibrahim S, Tanaka K, et al. Clerodane diterpenes isolated from Polyalthia longifolia induce apoptosis in human leukemia HL-60 cells. J Oleo Sci 2013;62(10):843-8.

33. Gupta VK, Verma S, Pal A, Srivastava SK, Srivastava PK, Darokar MP. In vivo efficacy and synergistic interaction of 16 $\alpha$-hydroxycleroda-3, 13 (14) Z-dien-15, 16-olide, a clerodane diterpene from Polyalthia longifolia against methicillin-resistant Staphylococcus aureus. Appl Microbiol Biotechnol 2013;97(20):9121-31.

34. Afolabi S, Olorundare O, Ninomiya M, Babatunde A, Mukhtar H, Koketsu M. Comparative antileukemic activity of a tetranorditerpene isolated from Polyalthia longifolia leaves and the derivative against human leukemia HL-60 cells. J Oleo Sci 2017;66:1169-74.

35. Bhattacharya AK, Chand HR, John J, Deshpande MV. Clerodane type diterpene as a novel antifungal agent from Polyalthia longifolia var. pendula. Eur J Med Chem 2015;94:1 7.

36. Zhang J, Jain SK, Jacob MR, Tekwani BL, Hufford CD, Muhammad I. Antileishmanial and Antimicrobial Clerodane Diterpenes from Polyalthia longifolia. Planta Med 2013;79(05):P88.

37. Jain PK, Patra A, Satpathy S, Jain S, Khan S. Antibacterial and antioxidant activities of 3-o-methyl ellagic acid from stem bark of Polyalthia longifolia Thw. Chiang Mai J Sci 2018;45(2):858-67.

38. Bose S, Byahatti VV, Souza MD, Bose A. Antioxidant and antimicrobial activities of isolated constituents from the bark of Polyalthia longifolia. Int J Green Pharm 2010;4(2):93.

39. Ghosh G, Subudhi BB, Badajena LD, Ray J, Mishra MK, Mishra SK. Antibacterial activity of Polyalthia longifolia var. angustifolia stem bark extract. Int $\mathbf{J}$ PharmTech Res 2011;3(1):256-60.

40. Satish S, Mohana DC, Ranhavendra MP, Raveesha KA. Antifungal activity of some plant extracts against important seed borne pathogens of Aspergillus sp. J Agric Technol 2007;3(1):109-19.

41. Shih YT, Hsu YY, Chang FR, Wu YC, Lo YC. 6-Hydroxycleroda-3, 13-dien-15, 16-olide protects neuronal cells from lipopolysaccharide-induced neurotoxicity through the inhibition of microglia-mediated inflammation. Planta Med 2010;76(02):120-7.

42. Nguyen HT, Vu TY, Chandi V, Polimati H, Tatipamula VB. Dual COX and 5-LOX inhibition by clerodane diterpenes from seeds of Polyalthia longifolia (Sonn.) Thwaites. Sci Rep 2020;10(1):1.

43. Wu TH, Cheng YY, Liou JR, Way TD, Chen CJ, Chen YH, et al. Clerodane diterpenes from Polyalthia longifolia var. pendula protect SK-N-MC human neuroblastoma cells from $\beta$-amyloid insult. RSC Adv 2014;4(45):23707-12.

44. Thiyagarajan $\mathrm{V}$, Lin SH, Chia YC, Weng CF. A novel inhibitor, 16-hydroxy-cleroda-3, 13-dien-16, 15-olide, blocks the autophosphorylation site of focal adhesion kinase (Y397) by molecular docking. Biochim Biophys Acta Gen Subj 2013;1830(8):4091-101.

45. Thiyagarajan V, Sivalingam KS, Viswanadha VP, Weng CF. 16-hydroxy-cleroda-3, 13-dien-16, 15-olide induced glioma cell autophagy via ROS generation and activation of 38 MAPK and ERK-1/2. Environ Toxicol Pharmacol 2016;45:202-11.

46. Afolabi SO, Olorundare OE, Babatunde A, Albrecht RM, Koketsu M, Syed DN, et al. Polyalthia longifolia extract triggers ER stress in prostate cancer cells concomitant with induction of apoptosis: insights from in vitro and in vivo studies. Oxid Med Cell Longev 2019;2019:6726312.

47. Liu C, Lee WC, Huang BM, Chia YC, Chen YC, Chen YC. 16-Hydroxycleroda-3, 13-dien-15, 16-olide inhibits the proliferation and induces mitochondrial-dependent apoptosis through Akt, mTOR and MEK-ERK pathways in human renal carcinoma cells. Phytomedicine 2017;36:95-107.

48. Chen YC, Huang BM, LeeWC, Chen YC. 16-Hydroxycleroda-3, 13-dien-15, 16-olide induces anoikis in human renal cell carcinoma cells: involvement of focal adhesion disassembly and signaling. Onco Targets Ther 2018;11:7679-90.

49. Rupachandra S, Sarada DV. Anti-proliferative and apoptotic properties of a peptide from the seeds of Polyalthia longifolia against human cancer cell lines. Indian J Biochem Biophys 2014;51:127-134.

50. Chen XX, Liang G, Chai WM, Feng HL, Zhou HT, Shi Y, et al. Antioxidant and antityrosinase proanthocyanidins from Polyalthia longifolia leaves. J Biosci Bioeng 2014;118(5):5837.

51. Annan K, Ekuadzi E, Asare C, Pistorius D, Oberer L, Gyan BA, et al. Antiplasmodial clerodane diterpene alkaloids from the stem bark of Polyalthia longifolia. Planta Med 2014;80(10):PD114.

52. Gbedema SY, Bayor MT, Annan K, Wright CW. Clerodane diterpenes from Polyalthia longifolia (Sonn) Thw. var. pendula: Potential antimalarial agents for drug resistant Plasmodium falciparum infection. J Ethnopharmacol 2015;169:176-82.

53. Edmond MP, Mostafa NM, El-Shazly M, Singab AN. Two 
clerodane diterpenes isolated from Polyalthia longifolia leaves: comparative structural features, anti-histaminic and anti-Helicobacter pylori activities. Nat Prod Res 2020:1-5.

54. Ebiloma GU, Igoli JO, Katsoulis E, Donachie AM, Eze A, Gray AI, et al. Bioassay-guided isolation of active principles from Nigerian medicinal plants identifies new trypanocides with low toxicity and no cross-resistance to diamidines and arsenicals. J Ethnopharmacol 2017;202:256-64.

55. Ebiloma GU, Katsoulis E, Igoli JO, Gray AI, De Koning HP. Multi-target mode of action of a Clerodane-type diterpenoid from Polyalthia longifolia targeting African trypanosomes. Sci Rep 2018;8(1):1-9.

56. Nguyen HT, Vu TY, Dakal TC, Dhabhai B, Nguyen XH, Tatipamula VB. Cleroda-4 (18), 13-dien-15, 16-olide as novel xanthine oxidase inhibitors: An integrated in silico and in vitro study. PloS one 2021;16(6):e0253572.

57. Chanda S, Dave R, Kaneria M, Shukla V. Acute oral toxicity of Polyalthia longifolia var. pendula leaf extract in Wistar albino rats. Pharm Biol 2012;50(11):1408-15. 